\section{Resistance of Daylily Cultivars to the Daylily Rust Pathogen, Puccinia hemerocallidis}

\author{
Daren S. Mueller \\ University of Georgia, Department of Plant Pathology, Georgia Station, \\ Griffin, GA 30223
}

\section{Jean L. Williams-Woodward \\ University of Georgia, Department of Plant Pathology, Athens, GA 30602}

\author{
James W. Buck ${ }^{1}$ \\ University of Georgia, Department of Plant Pathology, Georgia Station, \\ Griffin, GA 30223
}

Additional index words. Hemerocallis, landscape, perennial

\begin{abstract}
Daylilies (Hemerocallis sp.) have traditionally been considered to be pest-free. However, a rust disease caused by Puccinia hemerocallidis Thüm. has become an increasing problem in the United States since 2000. The objective of this study was to evaluate daylily cultivars for resistance to daylily rust. From a greenhouse evaluation of 84 inoculated cultivars, $14(17 \%)$ were classified as resistant; $13(15 \%)$ were classified as moderately resistant; $22(26 \%)$ were classified as moderately susceptible; and $35(42 \%)$ were classified as fully susceptible. Several cultivars displayed very high levels of resistance and may be utilized by breeders to develop cultivars with improved resistance to daylily rust. Information about the resistance and susceptibility of cultivars also will help commercial growers and gardeners select cultivars that have the potential to dramatically reduce damaging outbreaks of rust.
\end{abstract}

Daylilies are one of the most economically important ornamental plants cultivated in the United States. Daylilies are very popular perennials because they are available in several colors, shapes, and sizes; they are able to survive with very little care in a wide range of climates; and they are drought-resistant and, before daylily rust, almost disease- and pestfree (Williams-Woodward and Buck, 2002).

Daylily rust caused by Puccinia hemerocallidis was introduced into the United States in 2000 (Williams-Woodward et al., 2001) and has become an increasing problem for growers First found in Georgia, daylily rust has spread rapidly throughout the United States and has been reported as far north as Minnesota and west as Oregon and California (U.S. Dept. of Agriculture, 2002). Puccinia hemerocallidis is heteroecious. The uredinial/telial host is daylily and the alternate (spermagonia/aecial) host is Patrinia (Valerianaceae), a genus of rhizomatous or stoloiferous herbaceous perennials, some of which are grown as ornamentals (Jelitto and Schacht, 1990). However, infection of the alternate host is not required for the fungus to infect daylily. The uredinial or repeating spores stage on daylily can re-infect the same host plant, leading to epidemics. Bright

Received for publication 24 June 2002. Accepted for publication 3 Nov. 2002. We thank McCorkle's Nursery, Walter's Garden, and Singing Oakes Garden for their generous donation of plant material and financial support from the American Hemerocallis Society.

${ }^{1}$ To whom reprint requests should be addressed. Tel. (770) 412-4098; fax (770) 228-7305; e-mail jbuck@griffin.peachnet.edu

HortScience, Vol. 38(6), October 2003
Plant culture. Forty-one cultivars from Walter's Garden (Zeeland, Mich.) or Sing- ing Oakes Garden (Blythewood, S.C.) (set 1) and 43 cultivars from McCorkle's Nursery in Dearing, Ga. (set 2) were evaluated in the greenhouse. Plants were maintained in 3.8-L pots containing a commercial 9 bark : 1 sand mixture (McCorkle's Nursery). Cultivars in set 1 were placed on greenhouse benches in a rust-free polyhouse until initiating the experiment when pots were transferred to a greenhouse with average night/day temperature of 22 and $26{ }^{\circ} \mathrm{C}$. Cultivars from McCorkle's Nursery (set 2) were grown at their original site (Dearing, Ga.) until being transferred to the greenhouse. Plants were irrigated as needed and fertilized with Osmocote Plus 15\%-9\%-12\% (15.0N-3.96P-9.96K) controlled-release fertilizer (Scotts Co., Marysville, Ohio). Insect and arthropod pests were controlled using standard practices.

Pathogen culture and inoculation. An isolate of $P$. hemerocallidis was collected from an infected daylily plant ('Pardon Me') that was received by the Univ. of Georgia disease diagnosis clinic in 2000 (Williams-Woodward et al., 2001). This isolate was maintained on daylily plants of the same cultivar in the greenhouse with average temperatures of $24{ }^{\circ} \mathrm{C}$ day/22 ${ }^{\circ} \mathrm{C}$ night, respectively. For each experiment, urediniospores were collected from 10 to 12 d-old pustules using a vacuum spore collector, suspended in $0.05 \%(\mathrm{v} / \mathrm{v})$ Tween 20 (J.T. Baker, Phillipsburg, N.J.), and filtered through five layers of sterile cheesecloth. Spores were enumerated by hemocytometer, then diluted to $1-2 \times 10^{5}$ spores $/ \mathrm{mL}$ in $0.05 \%$ (v/v) Tween 20 . For each trial, three plants of each cultivar were watered to saturation, sprayed with the spore suspension until runoff, sealed individually in clear plastic $25 \mathrm{~cm} \times 20 \mathrm{~cm} \times 60 \mathrm{~cm}$ bags, and stored at $24{ }^{\circ} \mathrm{C}$ in the dark. After $24 \mathrm{~h}$, bags were removed and plants were transferred to the greenhouse. Foliage was not wetted during each experiment. Foliage was evaluated for rust $5 \times$ between 9 and $21 \mathrm{~d}$ after inoculation using a 1 to 5 rating scale. Ratings were $1=$ no disease; 2 = reduced lesion number and no sporulation; $3=$ reduced lesion number but not sporulation; 4 = slightly reduced lesion number and/or amount of sporulation; and 5 = fully susceptible (greatest number of lesions and/or amount of sporulation). This rating scale was based on the reaction of the Hemerocallis 'Pardon Me', which typically would have most lesions sporulating within 10 to $12 \mathrm{~d}$ (Mueller et al., unpublished). Area under disease progress curve (AUDPC) values were calculated in which: $X_{\mathrm{i}}=$ the foliar rating at the $i$ th observation; $t_{\mathrm{i}}=$ time (days between ratings) at the $i$ th observation; and $\mathrm{n}=$ total number of observations (Tooley and Grau, 1984). Plants in set 1 were cut off just above the crown after trial 1 was completed, treated with mancozeb at $1.8 \mathrm{~g} \cdot \mathrm{L}^{-1}$ (Fore FloXL, Dow AgroSciences, Indianapolis), then transferred to a rust-free polyhouse for $40 \mathrm{~d}$. These plants were then used in the second trial using the same techniques. For the plants from McCorkle's Nursery, a different set of plants was used for the second trial.

Statistical analysis. Data were subjected to analysis of variance using general linear 
Table 1. Foliar reaction of 41 commercial daylily cultivars inoculated with Puccinia hemerocallidis in the greenhouse (set 1).

\begin{tabular}{|c|c|c|c|c|c|}
\hline \multirow[b]{2}{*}{ Cultivar } & \multirow[b]{2}{*}{ Reaction $^{2}$} & \multicolumn{2}{|c|}{ Trial 1} & \multicolumn{2}{|c|}{ Trial 2} \\
\hline & & Rating $^{y}$ & $\mathrm{AUDPC}^{\mathrm{x}}$ & Rating $^{y}$ & AUDPC $^{x}$ \\
\hline Prairie Blue Eyes & $\mathrm{R}$ & 1.0 & 9.0 & 1.0 & 9.0 \\
\hline Carolyn Criswell & $\mathrm{R}$ & 1.0 & 10.8 & 1.0 & 9.0 \\
\hline Mardi Gras Parade & $\mathrm{R}$ & 1.0 & 9.0 & 1.0 & 11.0 \\
\hline Woodside Ruby & $\mathrm{R}$ & 1.7 & 10.7 & 1.7 & 12.7 \\
\hline Hush Little Baby & $\mathrm{R}$ & 1.0 & 10.5 & 1.3 & 13.2 \\
\hline Follow Your Heart & $\mathrm{R}$ & 1.3 & 10.2 & 1.3 & 15.7 \\
\hline Chicago Apache & $\mathrm{R}$ & 2.0 & 18.0 & 1.0 & 9.7 \\
\hline Buttered Popcorn & $\mathrm{R}$ & 1.0 & 12.0 & 1.0 & 16.0 \\
\hline Gordan Biggs & MR & 2.0 & 12.2 & 2.0 & 18.3 \\
\hline Texas Sunlight & MR & 2.0 & 17.2 & 1.7 & 14.2 \\
\hline Stella de Oro & MR & 2.0 & 16.5 & 2.0 & 19.0 \\
\hline Joan Senior & MR & 2.3 & 19.8 & 2.3 & 18.2 \\
\hline Ed Murray & MR & 3.0 & 22.7 & 2.7 & 18.0 \\
\hline Nanuq & MR & 2.0 & 20.3 & 2.3 & 21.3 \\
\hline Daring Deception & MR & 2.0 & 15.3 & 4.0 & 26.8 \\
\hline Bertie Ferris & MR & 2.0 & 19.8 & 3.0 & 24.2 \\
\hline Baja & MS & 3.0 & 26.8 & 3.0 & 26.3 \\
\hline Anzac & MS & 3.3 & 25.3 & 4.0 & 27.8 \\
\hline Mary's Gold & MS & 2.7 & 27.3 & 3.0 & 26.0 \\
\hline Razzmatazz & MS & 2.3 & 22.5 & 3.7 & 31.5 \\
\hline Tropical Reflection & MS & 3.0 & 26.5 & 4.0 & 27.7 \\
\hline Advance Party & MS & 4.0 & 28.8 & 3.3 & 25.5 \\
\hline Ice Carnival & MS & 3.0 & 24.3 & 4.0 & 31.3 \\
\hline Midnight Rambler & MS & 3.0 & 28.3 & 3.3 & 27.8 \\
\hline Cherry Cheeks & MS & 3.3 & 31.8 & 3.0 & 24.8 \\
\hline Pearl Harbor & MS & 2.3 & 31.3 & 3.0 & 26.3 \\
\hline My Melinda & $\mathrm{S}$ & 4.0 & 37.2 & 4.0 & 29.2 \\
\hline Catherine Neal & $\mathrm{S}$ & 5.0 & 38.2 & 3.7 & 32.5 \\
\hline Enchanted Rainbow & $\mathrm{S}$ & 4.3 & 32.2 & 5.0 & 38.5 \\
\hline Siloam Plum Tree & $\mathrm{S}$ & 5.0 & 38.8 & 4.7 & 36.8 \\
\hline Chorus Line & $\mathrm{S}$ & 4.7 & 41.3 & 4.0 & 34.8 \\
\hline Along the Way & $\mathrm{S}$ & 5.0 & 41.7 & 5.0 & 36.0 \\
\hline Barbara Mitchell & $S$ & 5.0 & 41.0 & 4.3 & 38.3 \\
\hline Strawberry Candy & $\mathrm{S}$ & 5.0 & 42.3 & 5.0 & 37.3 \\
\hline Mary Todd & $\mathrm{S}$ & 5.0 & 43.5 & 4.7 & 37.7 \\
\hline Hyperion & $\mathrm{S}$ & 5.0 & 45.0 & 4.7 & 36.3 \\
\hline Love Those Eyes & $\mathrm{S}$ & 5.0 & 42.8 & 5.0 & 41.2 \\
\hline Bright Sunset & $\mathrm{S}$ & 5.0 & 42.5 & 5.0 & 44.7 \\
\hline Rocket City & $\mathrm{S}$ & 5.0 & 44.3 & 5.0 & 43.8 \\
\hline Little Grapette & $\mathrm{S}$ & 5.0 & 45.0 & 5.0 & 44.7 \\
\hline Christmas Carol & $\mathrm{S}$ & 5.0 & 45.0 & 5.0 & 45.0 \\
\hline Pardon Me (control) & S & 5.0 & 45.0 & 5.0 & 45.0 \\
\hline $\operatorname{LSD}_{(0.05)}$ & & 0.7 & 4.9 & 0.6 & 4.6 \\
\hline $\mathrm{CV}(\%)$ & & 14.8 & 11.0 & 12.2 & 10.8 \\
\hline
\end{tabular}

${ }^{2} \mathrm{R}=$ resistant; $\mathrm{MR}=$ moderately resistant; $\mathrm{MS}=$ moderately susceptible; and $\mathrm{S}=$ susceptible.

${ }^{y}$ Rating taken $21 \mathrm{~d}$ after inoculation using a 1 to 5 rating scale where: $1=$ no disease; 2 = reduced lesion number and no sporulation; 3 = reduced lesion number but not sporulation; $4=$ slightly reduced lesion number and/or amount of sporulation; and $5=$ fully susceptible. This rating scale was based on the reaction of the cultivar 'Pardon Me', which typically would have most lesions sporulating within 10 to $12 \mathrm{~d}$.

${ }^{x}$ AUDPC $=$ area under disease progress curve in which: $X_{\mathrm{i}}=$ the foliar rating at the $i$ th observation; $t_{\mathrm{i}}=$ time (days between ratings) at the $i$ th observation; and $\mathrm{n}=$ total number of observations.

models procedure (PROC GLM) of SAS (SAS Institute, Cary, N.C.). Trials and replications were considered random variables, while daylily cultivars were considered a fixed variable. Means were separated by Fisher's protected least significant differences (LSD) at $P \leq 0.05$. Cultivar ratings and AUDPC values from trials one and two for each set were compared using Pearson's correlation (PROC CORR) of SAS.

\section{Results and Discussion}

The daylily cultivars screened for resistance to $P$. hemerocallidis are listed in Tables 1 and 2 .
Table 2. Reaction of 43 commercial daylily cultivars inoculated with Puccinia hemerocallidis in the greenhouse (set 2 ).

\begin{tabular}{|c|c|c|c|c|c|}
\hline \multirow[b]{2}{*}{ Cultivar } & \multirow[b]{2}{*}{ Reaction $^{2}$} & \multicolumn{2}{|c|}{ Trial 1} & \multicolumn{2}{|c|}{ Trial 2} \\
\hline & & $\overline{\text { Rating }^{y}}$ & AUDPC $^{x}$ & Rating $^{y}$ & AUDPC $^{x}$ \\
\hline Green Flutter & $\mathrm{R}$ & 1.0 & 9.0 & 1.0 & 10.0 \\
\hline Plum Perfect & $\mathrm{R}$ & 1.0 & 10.7 & 1.3 & 10.0 \\
\hline Frankly Scarlet & $\mathrm{R}$ & 1.3 & 11.5 & 1.0 & 10.3 \\
\hline Mama Cha Cha & $\mathrm{R}$ & 2.7 & 11.5 & 2.7 & 11.2 \\
\hline Chinese Scholar & $\mathrm{R}$ & 1.3 & 10.8 & 1.3 & 12.0 \\
\hline Charlie Pierce Memorial & $\mathrm{R}$ & 2.0 & 19.2 & 1.3 & 19.8 \\
\hline Black Eyed Stella & MR & 2.0 & 21.3 & 2.3 & 20.5 \\
\hline Nagasaki & MR & 2.3 & 18.7 & 3.0 & 24.3 \\
\hline Siloam Double Classic & MR & 3.0 & 18.8 & 2.3 & 25.8 \\
\hline Mini Pearl & MR & 2.0 & 23.5 & 2.7 & 22.0 \\
\hline Little Business & MR & 2.3 & 19.3 & 3.7 & 27.3 \\
\hline Little Sweet Sue & MS & 3.7 & 28.7 & 3.7 & 19.5 \\
\hline Susie Wong & MS & 3.3 & 27.2 & 3.7 & 23.7 \\
\hline Seeing Red & MS & 3.3 & 26.3 & 2.7 & 26.2 \\
\hline Little Heavenly Angel & MS & 3.7 & 26.8 & 3.3 & 26.7 \\
\hline Patio Parade & MS & 4.0 & 29.0 & 3.3 & 25.0 \\
\hline Witches Wink & MS & 2.3 & 21.0 & 4.0 & 34.5 \\
\hline Todd Monroe & MS & 3.3 & 26.3 & 4.0 & 29.7 \\
\hline Amy Louise & MS & 4.0 & 29.2 & 4.0 & 27.8 \\
\hline Jeune Tom & MS & 3.3 & 27.8 & 4.0 & 29.8 \\
\hline Magic Obsession & MS & 3.7 & 30.3 & 4.0 & 28.2 \\
\hline Grape Magic & MS & 3.7 & 28.7 & 4.3 & 31.7 \\
\hline Becky Lynn & MS & 3.7 & 28.8 & 4.3 & 33.3 \\
\hline Judith & $\mathrm{S}$ & 4.7 & 31.0 & 4.7 & 33.5 \\
\hline Red Rum & $\mathrm{S}$ & 4.7 & 30.3 & 4.3 & 34.3 \\
\hline Leebea Orange Crush & $\mathrm{S}$ & 4.3 & 32.3 & 4.3 & 32.8 \\
\hline Cranberry Baby & $\mathrm{S}$ & 4.0 & 26.7 & 4.7 & 38.8 \\
\hline Little Maggie & $\mathrm{S}$ & 4.7 & 35.7 & 4.0 & 34.0 \\
\hline Little Grapette & $\mathrm{S}$ & 4.3 & 34.3 & 4.7 & 38.3 \\
\hline Elegant Candy & $\mathrm{S}$ & 4.7 & 39.2 & 4.7 & 35.8 \\
\hline Lavender Blush & $\mathrm{S}$ & 5.0 & 41.3 & 4.7 & 34.2 \\
\hline Night Beacon & $\mathrm{S}$ & 5.0 & 37.8 & 4.7 & 41.0 \\
\hline Custard Candy & $\mathrm{S}$ & 5.0 & 42.0 & 4.7 & 39.8 \\
\hline David Kirchhoff & $\mathrm{S}$ & 5.0 & 44.7 & 4.7 & 38.3 \\
\hline Always Afternoon & $\mathrm{S}$ & 4.7 & 39.7 & 5.0 & 43.8 \\
\hline Apollodorus & $\mathrm{S}$ & 5.0 & 43.2 & 4.7 & 40.7 \\
\hline Ancient Glow & $\mathrm{S}$ & 5.0 & 43.8 & 3.7 & 40.7 \\
\hline Here Comes Sallyann & $\mathrm{S}$ & 5.0 & 41.8 & 5.0 & 43.0 \\
\hline Tickled Pink & $\mathrm{S}$ & 5.0 & 44.7 & 4.7 & 40.3 \\
\hline Seductor & $\mathrm{S}$ & 5.0 & 44.7 & 5.0 & 41.2 \\
\hline Creative Art & $\mathrm{S}$ & 5.0 & 45.0 & 5.0 & 43.7 \\
\hline Benchmark & $\mathrm{S}$ & 5.0 & 45.0 & 5.0 & 44.7 \\
\hline Raspberry Candy & $\mathrm{S}$ & 5.0 & 45.0 & 5.0 & 44.7 \\
\hline Pardon Me (control) & S & 5.0 & 44.7 & 5.0 & 45.0 \\
\hline $\operatorname{LSD}_{(0.03}$ & & 1.1 & 7.1 & 1.0 & 6.8 \\
\hline $\mathrm{CV}(\%)$ & & 18.1 & 14.7 & 16.2 & 13.8 \\
\hline
\end{tabular}

${ }^{z, y, x}$ See footnotes for Table 1 .
Trials one and two were positively correlated $(P<0.0001)$ for cultivar rating $(\mathrm{r}=0.87 ; \mathrm{r}=$ $0.76)$ and AUDPC values $(r=0.90 ; r=0.80)$ for set 1 and set 2 , respectively. These high correlation coefficients indicate reactions to $P$. hemerocallidis were similar for both trials in each set of cultivars, despite the application of mancozeb $40 \mathrm{~d}$ prior to the second trial in set 1. Cultivars were separated into four groups based on their susceptibility to rust. Resistant (R) plants had no or very few lesions. If lesions did occur on the resistant plants, they were restricted by a hypersensitive reaction or did not sporulate (Fig. 1 A and B). Moderately resistant (MR) plants had very few lesions compared to 'Pardon Me' plants but produced some urediniospores. Moderately susceptible (MS) plants had slightly reduced lesion number or delayed sporulation compared to 'Pardon Me' plants. Susceptible plants were similar to 'Pardon Me' in number of lesions and level of sporulation (Fig. 1E). Of the 41 cultivars in set 1, eight (20\%) were classified as R; eight $(20 \%)$ were classified as MR; $10(24 \%)$ were classified as MS; and $15(36 \%)$ were classified as $\mathrm{S}$ (Table 1). Of the 43 cultivars in set 2 , six (14\%) were classified as R; five (12\%) were classified as MR; 12 (28\%) were classified as MS; and $20(46 \%)$ were classified as S (Table 2). Combined, $32 \%$ of the cultivars were either R or MR. Data on flower color and size, foliage type (dormant vs. evergreen), and ploidy level were collected for each cultivar, but none of these plant traits exhibited a significant correlation with rust resistance (data not presented).

Different reactions to daylily rust have been reported previously (Williams-Woodward and 

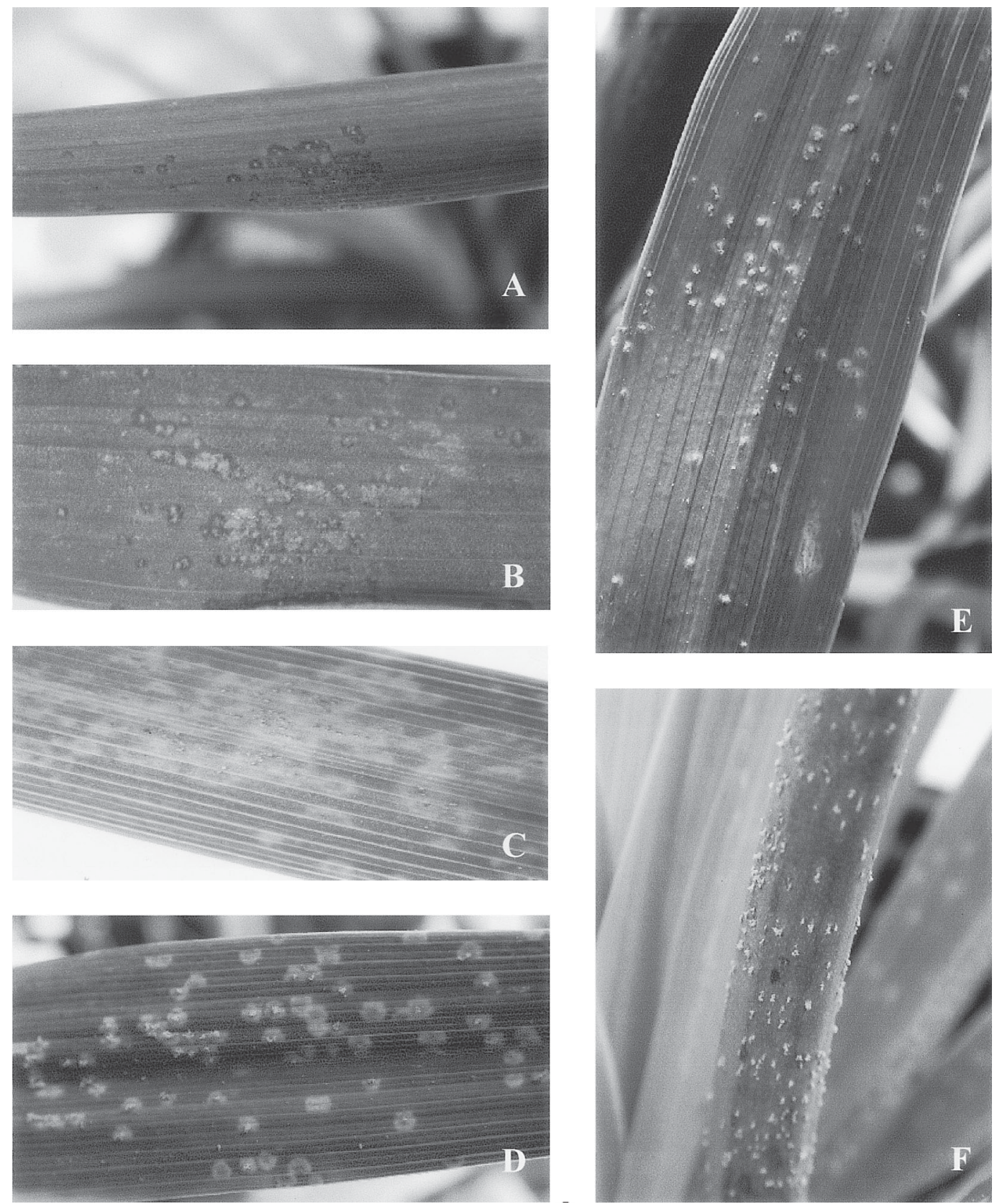

Fig. 1. (A) Small lesions that did not sporulate ('Buttered Popcorn', resistant); (B) larger lesions that did not sporulate ('Nanuq', moderately resistant); (C) very large yellow lesions that did not sporulate until $18 \mathrm{~d}$ after inoculation, if at all ('Ice Carnival', moderately susceptible); (D) large yellow-orange lesions that sporulated 12-14 d after inoculation ('Lavender Blush', susceptible); (E) bright yellow-orange lesions ('Pardon Me', susceptible); and (F) lesions on scape.

Buck, 2001). Symptoms on the foliage of 'Pardon Me' were described as bright yellow spots to streaks, while symptoms on 'Gordon Condon' were described as water-soaked tan spots with darker borders (Williams-Woodward and Buck, 2001). In our studies, we also observed a wide variety of symptoms. For example, 'Pardon Me' produced small bright yellow spots within $4 \mathrm{~d}$ and these spots turned into sporulating lesions within 8 to $12 \mathrm{~d}$ after inoculation (Fig. 1E). Cultivars like 'Ice Carnival', 'Mini Pearl', and 'Seeing Red' produced large, dull yellow spots that did not start sporulating until $18 \mathrm{~d}$ after inoculation or later (Fig. 1C). However, cultivars like 'Lavender Blush' had large yellow lesions that started sporulating as early as 12 to $14 \mathrm{~d}$ after inoculation (Fig. 1D). A few cultivars like 'Buttered Popcorn', 'Charlie
Pierce Memorial', 'Follow Your Heart', and 'Gordon Biggs' had very few restricted lesions produced on the lowest leaves; however, these lesions did not sporulate (Fig. 1 A and B). On some cultivars, such as 'Here Comes Sallyann' and 'Bright Sunset', lesions were formed on the scape as well as the leaves (Fig. 1F).

Currently, there are no data indicating the presence of different races of $P$. hemerocallidis. Hernandez et al. (2002) compared the internal transcribed spacer (ITS) region of P. hemerocallidis isolates from different geographical areas in the United States to isolates from Asia. The variation in the ITS sequences between Asia and the United States and within each geographical area indicated that the specimens are the same species. In our study, we used $P$. hemerocallidis from a single source. Resistant and susceptible cultivars identified in our study could be used to assess a collection of $P$. hemerocallidis for genetic differences.

Fungicides such as azoxystrobin (Heritage, Syngenta Crop Protection, Greensboro, N.C.) and chlorothalonil (e.g., Daconil Ultrex, Syngenta Crop Protection) have been shown to reduce $P$. hemerocallidis urediospore germination (Buck and Williams-Woodward, 2001) and lesion development (Buck and WilliamsWoodward, 2003). However, control measures, such as fungicides, have dramatically increased daylily production costs. The use of resistant cultivars would reduce production costs by eliminating, reducing, or delaying rust infection. Furthermore, cultivars with resistance provide nurseries and enthusiasts with an environmentally safe option for controlling 
daylily rust and may be used by breeders to develop future cultivars.

\section{Literature Cited}

Baxter, G. 1999. Hemerocallis check list 1994-1998. Amer. Hemerocallis Soc., Kansas City, Kans.

Buck, J.W. and J.L. Williams-Woodward. 2001. In vitro fungicide sensitivity and optimum germination temperature of the daylily rust pathogen, Pucciniahemerocallidis. Proc. Southern Nursery Assn. Res. Conf. 46:237-241.

Buck, J.W. and J.L. Williams-Woodward. 2003. The effect of fungicides on urediniospore germination and disease development of daylily rust. Crop Prot. 22:135-140.

Hernandez, J.R., M.E. Palm, and L.A. Castlebury. 2002. Puccinia hemerocallidis, cause of daylily rust, a newly introduced disease in the Americas.
Plant Dis. 86:1194-1198.

Jelitto, L. and W. Schacht. 1990. Hardy herbaceous perennials, vol. II, L-Z. Timber Press, Portland, Ore.

Monroe, W.C. 1994. Hemerocallis check list 1989-1993. Amer. Hemerocallis Soc., Kansas City, Kans.

Monroe, W.E. 1973. Hemerocallis check list July 1, 1957 to July 1, 1973. Reprinted (1995). Amer. Hemerocallis Soc., Kansas City, Kans.

Monroe, W.E. 1984. Hemerocallis check list July 1, 1973 to December 31, 1983. Amer. Hemerocallis Soc., Baton Rouge, La.

Monroe, W.E. and W.C. Monroe. 1989. Hemerocallis check list January 1, 1984 to December 31, 1988. Amer. Hemerocallis Soc., Kansas City, Kans.

Stuntz M.F., P. Voth, E.A. Holl, W.B. Flory, H.I. Tuggle, and W.E. Monroe. 1957. Hemerocallis check list 1893 to July 1, 1957. Amer. Hemero- callis Soc., Baton Rouge, La.

Tooley, P.W. and C.R. Grau. 1984. Field characterization of rate-reducing resistance to Phytophthora megasperma f. sp. glycinea in soybean. Phytopathology 74:1201-1208.

U.S. Dept. of Agriculture. 2002. National Plant Board Daylily Rust Pest Alert. http: //www.aphis.usda.gov.npb/daylily.html.

Williams-Woodward, J.L. and J.W. Buck. 2001. Daylily rust caused by Puccinia hemerocallidis: A new disease on daylily in the U.S. Proc. Southern Nursery Assn. Res. Conf. 46:234-236.

Williams-Woodward, J.L. and J.W. Buck. 2002. Diseases and pests of daylily, p. 222-239. In: F. Gatlin and J. Brennan (eds.). New daylily handbook. Kansas City, Mo.

Williams-Woodward, J.L., J.F. Hennen, K.W. Parda, and J.M. Fowler. 2001. First report of daylily rust in the United States. Plant Dis. 85:1121. 